\title{
Ping-Pong Electron Transfer through DNA ${ }^{* *}$
}

\author{
Benjamin Elias [Prof.], \\ Chimie Organique et Médicinale, Université catholique de Louvain (Belgium) \\ Joseph C. Genereux, and \\ Division of Chemistry and Chemical Engineering, California Institute of Technology, Pasadena, CA \\ 91125 (USA) \\ Jacqueline K. Barton * \\ Division of Chemistry and Chemical Engineering, California Institute of Technology, Pasadena, CA \\ 91125 (USA)
}

DNA charge transport (CT) chemistry has been characterized in detail[1] owing to its utility in the construction of DNA-based sensors and nanoscale devices.[2-4] Interestingly, recent evidence also points to the application of this chemistry within the cell in the context of DNA damage and repair.[5] Both DNA hole transport (HT) and electron transport (ET) have been explored using spectroscopy,[6] biochemical assays,[7] and DNA electrochemistry.[8] In reporting on DNA-mediated HT, $N 2$-cyclopropylguanine and $N 6$-cyclopropyladenine $\left({ }^{\mathrm{CP}} \mathrm{A}\right)$ have been useful hole traps owing to their low oxidation potentials and their fast rates of ring opening $\left(10^{-11} \mathrm{~s}\right)$ upon one-electron oxidation (Scheme 1).[9] Similarly, owing to their redox potentials, [10] the pyrimidines $N 4$-cyclopropylcytosine $\left({ }^{\mathrm{CP}} \mathrm{C}\right)[11]$ and 5 -bromouridine $\left({ }^{\mathrm{Br}} \mathrm{U}\right)$, [12] have been sensitive probes for DNA-mediated ET.

Recently, direct comparisons of HT with ET were carried out using a charge injector strongly coupled to the base stack and able to oxidize or reduce bases from a distance within the same DNA assembly.[13,14] Taking advantage of the powerful photochemistry of Ir III

biscyclometalated complexes, we have shown that the $\left[\operatorname{Ir}(\mathrm{ppy})_{2}(\mathrm{dppz})\right]^{1+}$, functionalized through a modified dipyrido[3,2-a:2',3'-c]phenazine (dppz'; ppy=2-phenylpyridine; Scheme 1), can serve both as a photooxidant and reductant of distal DNA bases.[13,15] Strikingly, we found that DNA HT and ET have similar characteristics; both show a remarkably shallow distance dependence in their reactions as well as an equal sensitivity to perturbations in stacking of the intervening DNA bridge.

Significantly, although the excited state of the Ir ${ }^{\mathrm{III}}$ complex is sufficiently potent to oxidize guanine or adenine,[15] efficient electron injection into DNA required the use of the flashquench technique.[16] Indeed, the excited state of the $\mathrm{Ir}^{\mathrm{III}}$ complex is not sufficiently longlived $(\tau<10 \mathrm{~ns})$ in water to photoreduce ${ }^{\mathrm{B}} \mathrm{U}$ from a distance in substantial yield.[13] When sodium ascorbate is used as an external reducing agent, however, photolysis of the tethered Ir III complex generates a long-lived ground-state reductant, which is in turn able to induce significant ${ }^{\mathrm{Br}} \mathrm{U}$ decomposition from a distance.

Herein we describe a novel Ir system that is able to promote the reduction of pyrimidine bases from a distance without the presence of an external quencher. Instead, DNA-mediated ET is triggered by DNA-mediated HT. Thus, photoactivation of these Ir assemblies results in both

\footnotetext{
** This work was supported by the NIH (GM49216).

(C) 2008 Wiley-VCH Verlag GmbH \& Co. KGaA, Weinheim

*Fax: (+1)6265774976, E-mail: jkbarton@ caltech.edu.
} 
a forward and a reverse pattern for charge migration, which we term "ping-pong" electron transfer through DNA (Scheme 1).

We have designed Ir-DNA conjugates containing two modified bases embedded in an AT tract,[17] a ${ }^{\mathrm{CP}} \mathrm{A}$ for hole injection, and either a ${ }^{\mathrm{Br}} \mathrm{U}$ or a ${ }^{\mathrm{CP}} \mathrm{C}$ as an electron trap (Scheme 2). For synthetic reasons, we required three different strands, one short strand (5-mer) covalently tethered to the $\mathrm{Ir}^{\mathrm{III}}$ complex, one strand (13-mer) containing a ${ }^{\mathrm{CP}} \mathrm{A}$-modified base, and one complementary strand (18-mer) containing either a ${ }^{\mathrm{Br}} \mathrm{U}$ or ${ }^{\mathrm{CP}} \mathrm{C}$. It should be noted that 1$)$ the presence of a nick in the phosphate backbone of the DNA helix does not affect the CT process, [18] 2) the intercalative dppz' unit stabilizes the short Ir strand in the duplex,[19] and 3) the irreversible ring-opening of ${ }^{\mathrm{CP}} \mathrm{A}$ precludes back ET.

Figure 1 shows the decomposition percentage of ${ }^{\mathrm{CP}} \mathrm{A}$ and ${ }^{\mathrm{Br}} \mathrm{U}$ obtained after 30 min irradiation of the DNA assemblies at $365 \mathrm{~nm}$ as a function of the ${ }^{\mathrm{CP}} \mathrm{A}$ position (see the Experimental Section). Clearly, both modified bases undergo a decomposition reaction upon photolysis. No decomposition of ${ }^{\mathrm{Br}} \mathrm{U}$ is observed without both ${ }^{\mathrm{CP}} \mathrm{A}$ and tethered $\mathrm{Ir}^{\mathrm{III}}$ complex in the assembly. Moreover, the extent of ${ }^{\mathrm{Br}} \mathrm{U}$ decomposition varies with the position of ${ }^{\mathrm{CP}} \mathrm{A}$. We therefore see that the ${ }^{\mathrm{Br}} \mathrm{U}$ decomposition is correlated with ${ }^{\mathrm{CP}} \mathrm{A}$ ring-opening. We ascribe this correlation to the ping-pong reaction, where the highly oxidizing $\operatorname{Ir}^{\mathrm{III}}$ excited state[13,15] is reductively quenched in an intraduplex reaction by the distal ${ }^{\mathrm{CP}} \mathrm{A}$ (migration of a "ping" electron); the ground-state Ir reductant, formed by the intraduplex flash-quench scheme, is identical to the one generated using an external quencher[13] and is capable of reducing ${ }^{B r} U$ by ET through the DNA stack (migration of a "pong" electron).

We have further tested the ping-pong reaction using ${ }^{\mathrm{CP}} \mathrm{C}$ as a reductive probe, and here substantial yields of decomposition of the modified base are observed.[11,15] While ${ }^{\mathrm{CP}} \mathrm{C}$ can be either photoreduced or photooxidized by the $\mathrm{Ir}^{\mathrm{III}}$ complex, it has been shown that this modified base is reductively ring-opened by excited Ir when embedded in a thymine stack. [15] Figure 2 shows the decomposition percentages of ${ }^{\mathrm{CP}} \mathrm{A}$ and ${ }^{\mathrm{CP}} \mathrm{C}$ as a function of ${ }^{\mathrm{CP}} \mathrm{A}$ position in Ir-DNA conjugates, which contain ${ }^{\mathrm{CP}} \mathrm{A}$ within an $\mathrm{A}$ tract and ${ }^{\mathrm{CP}} \mathrm{C}$ on the complementary strand. Here, a higher relative yield is obtained for the decomposition of the reductive probe compared to that of ${ }^{\mathrm{Br}} \mathrm{U}$. In fact, the ${ }^{\mathrm{CP}} \mathrm{C}$ decomposition is stoichiometric with ${ }^{\mathrm{CP}} \mathrm{A}$ decomposition. Importantly, in the absence of ${ }^{\mathrm{CP}} \mathrm{A}$, little ${ }^{\mathrm{CP}} \mathrm{C}$ decomposition is obtained; the presence of ${ }^{\mathrm{CP}} \mathrm{A}$ is required for significant ${ }^{\mathrm{CP}} \mathrm{C}$ yields of decomposition. Also, no decomposition is observed without the presence of tethered IrIII complex. Furthermore, no change in ${ }^{\mathrm{CP}} \mathrm{C}$ decomposition is found in assemblies where ${ }^{\mathrm{CP}} \mathrm{C}$ is base-paired to an inosine (Figure 2); if decomposition of ${ }^{\mathrm{CP}} \mathrm{C}$ were to occur through photooxidation, an enhancement in yield would be evident without the competitive oxidative guanine sink.[20] Thus ${ }^{\mathrm{CP}_{C}}$ ringopening here results from reduction by DNA-mediated ET and not from a photooxidation process. The ping-pong reaction is, then, highly efficient. Figure 2 shows also the decomposition yields for ${ }^{\mathrm{CP}} \mathrm{C}$ in the absence of ${ }^{\mathrm{CP}} \mathrm{A}$, both without (gray bars) and with (white bars) an external reductive quencher (sodium ascorbate) known to reductively quench the $\mathrm{Ir}^{\mathrm{III}}$ excited state.[13] The ground-state reduced metallic species, generated through ${ }^{\mathrm{CP}} \mathrm{A}$ oxidation, can effectively reduce the distal ${ }^{\mathrm{CP}} \mathrm{C}$, indeed comparably to an external reductive quencher.

The sensitivity of DNA CT to DNA structure and dynamics is illustrated also for the ping-pong reaction through variations in the DNA sequence. Despite equal overall energetics, the decomposition efficiency in these assemblies is seen to depend upon the position of the redox trap in the double helix. For instance, exchanging the ${ }^{\mathrm{CP}} \mathrm{A}$ and ${ }^{\mathrm{CP}} \mathrm{C}$ and the $\mathrm{AT}$ tract from one strand to the other significantly affects the overall yield, especially for reduction (Figure 3). This result is consistent with sequence variations seen earlier for DNA-mediated ET, and more generally for CT in DNA with variations in the intervening base stack.[13,21] 
Thus, for the first time, DNA-mediated HT and ET have been triggered consecutively within the same DNA duplex by irradiation of a unique charge injector. The ping-pong reaction likely involves hole migration primarily through the purine strand with electron migration facilitated by stacked pyrimidines. Critically, the analogous parameters govern both HT and ET through the DNA base-pair stack.

\section{Experimental Section}

All DNA oligonucleotides were synthesized using standard phosphoramidite chemistry. Strands containing a ${ }^{\mathrm{CP}} \mathrm{A}$ or ${ }^{\mathrm{CP}} \mathrm{C}$ were synthesized by placing an $O 6$-phenylinosine or 4thiouridine at the target ${ }^{\mathrm{CP}} \mathrm{A}$ or ${ }^{\mathrm{CP}} \mathrm{C}$ site, respectively. After $16 \mathrm{~h}$ incubation at $60^{\circ} \mathrm{C}$ in $6 \mathrm{~m}$ aqueous cyclopropylamine leading to simultaneous substitution reaction, cleavage from the solid support, and deprotection, the strands were purified using reversed-phase HPLC and characterized by MALDI mass spectrometry. $\left[\operatorname{Ir}(\mathrm{ppy})_{2}(\mathrm{dppz})^{\prime}\right]^{+}$was synthesized and covalently tethered to DNA oligonucleotides according to previously described methods.[13, 15] Ir-DNA conjugates were prepared by combining equimolar amounts $(1: 1: 1)$ of the desired DNA single strands. After annealing (solution was heated to $90^{\circ} \mathrm{C}$ for $5 \mathrm{~min}$, then slowly cooled down to $15^{\circ} \mathrm{C}$ over a period of $3 \mathrm{~h}$ ), all of the resulting duplexes showed melting temperatures above ambient temperature.

Aliquots $(30 \mu \mathrm{L})$ of the Ir-DNA conjugates ( $10 \mu_{\mathrm{M}}$ in $50 \mathrm{~m}_{\mathrm{M}}$ TrisHCl, $\left.\mathrm{pH} 7.0\right)$ were irradiated for $30 \mathrm{~min}$ at $365 \mathrm{~nm}$ (Hg/Xe lamp, 1000W, with monochromator). Subsequent cleavage into deoxynucleosides upon digestion with phosphodiesterase I and alkaline phosphatase was carried out and the results analyzed by HPLC. The percentage of base decomposition, that is, the amount of decomposed ${ }^{\mathrm{CP}} \mathrm{A},{ }^{\mathrm{CP}} \mathrm{C}$, or ${ }^{\mathrm{Br}} \mathrm{U}$, was determined by subtracting the ratio of the area under the peak of the undecomposed base in an irradiated sample over that in a nonirradiated sample from unity, with adenine or inosine as an internal HPLC standard. Irradiation experiments were repeated three times and the results averaged.

\section{References}

1. a) Carell T, Behrens C, Gierlich J. Org. Biomol. Chem 2003;1:2221. [PubMed: 12945689]O'Neill, MA.; Barton, JK. Charge Transfer in DNA: From Mechanism to Application. Wagenknecht, HA., editor. New York: Wiley; 2005. p. 27 c) Conwell EM. Proc. Natl. Acad. Sci. USA 2005;102:8795. [PubMed: 15956188] d) Giese B. Top. Curr. Chem 2004;236:27.

2. a) Bandyopadhyay A, Ray AK, Sharma AK, Khondaker SI. Nanotechnology 2006;17:227. b) Porath D, Cuniberti G, Di Felice R. Top. Curr. Chem 2004;237:183. c) Clever GH, Kaul C, Carell T. Angew. Chem 2007;119:6340.Angew. Chem. Int. Ed 2007;46:6226. d) Guo X, Gorodetsky AA, Hone J, Barton JK, Nuckolls C. Nat. Nanotechnol 2008;3:163. [PubMed: 18654489]

3. a) Drummond TG, Hill MG, Barton JK. Nat. Biotechnol 2003;21:1192. [PubMed: 14520405] b) Yang Y, Wang Z, Yang M, Li J, Zheng F, Shen G, Yu R. Anal. Chim. Acta 2007;584:268. [PubMed: 17386614] c) Wang X, Ozkan CS. Nano Lett 2008;8:308.

4. a) Boon EM, Ceres DM, Hill MG, Drummond TD, Barton JK. Nat. Biotechnol 2000;18:1096. [PubMed: 11017050] b) Boon EM, Salas JW, Barton JK. Nat. Biotechnol 2002;20:282. [PubMed: 11875430] c) Boal AK, Barton JK. Bioconjugate Chem 2005;16:312.

5. Merino EJ, Boal AK, Barton JK. Curr. Opin. Chem. Biol 2008;12:229. [PubMed: 18314014]

6. a) Wan C, Fiebig T, Kelley SO, Treadway CR, Barton JK, Zewail AH. Proc. Natl. Acad. Sci. USA 1999;96:6014. [PubMed: 10339533] b) Takada T, Kawai K, Cai X, Sigimoto A, Fujitsuka M, Majima T. J. Am. Chem. Soc 2004;126:1125. [PubMed: 14746481] c) Lewis FD, Zhu H, Daublain P, Cohen B, Wasielewski MR. Angew. Chem 2006;118:8150.Angew. Chem. Int. Ed 2006;45:7982.

7. a) Hall DB, Holmlin RE, Barton JK. Nature 1996;382:731. [PubMed: 8751447] b) Ghosh A, Joy A, Schuster GB, Douki T, Cadet J. Org. Biomol. Chem 2008;6:916. [PubMed: 18292885] c) Nakatani K, Saito I. Top. Curr. Chem 2004;236:163. d) Nunez ME, Hall DB, Barton JK. Chem. Biol 1999;6:85. [PubMed: 10021416] 
8. a) Gorodetsky AA, Barton JK. Langmuir 2006;22:7917. [PubMed: 16922584] b) Kelley SO, Hill MG, Barton JK. Angew. Chem 1999;111:991.Angew. Chem. Int. Ed 1999;38:941. c) Drummond TG, Hill MG, Barton JK. J. Am. Chem. Soc 2004;126:15010. [PubMed: 15547981]

9. a) Nakatani K, Dohno C, Saito I. J. Am. Chem. Soc 2001;123:9681. [PubMed: 11572693] b) Musa OM, Horner JH, Shahin H, Newcomb M. J. Am. Chem. Soc 1996;118:3862. c) O’Neill MA, Dohno C, Barton JK. J. Am. Chem. Soc 2004;126:1316. [PubMed: 14759170] d) Dohno C, Ogawa A, Nakatani K, Saito I. J. Am. Chem. Soc 2003;125:10154. [PubMed: 12926921]

10. a) Steenken S, Telo JP, Novais LP, Candeias LP. J. Am. Chem. Soc 1992;114:4701. b) Seidel CAM, Schultz A, Sauer MHM. J. Phys. Chem 1996;100:5541.

11. a) Lu W, Vicic DA, Barton JK. Inorg. Chem 2005;44:7970. [PubMed: 16241147] b) Shao F, O’Neill MA, Barton JK. Proc. Natl. Acad. Sci. USA 2004;101:17914. [PubMed: 15604138]

12. a) Manetto A, Breeger S, Chatgilialoglu C, Carell T. Angew. Chem 2006;118:325.Angew. Chem. Int. Ed 2006;45:318. b) Cook GP, Greenberg MM. J. Am. Chem. Soc 1996;118:10025. c) Ito T, Rokita SE. J. Am. Chem. Soc 2003;125:11480. [PubMed: 13129334]

13. Elias B, Shao F, Barton JK. J. Am. Chem. Soc 2008;130:1152. [PubMed: 18183988]

14. Valis L, Wang Q, Raytchev M, Buchvarov I, Wagenknecht HA, Fiebig T. Proc. Natl. Acad. Sci. USA 2006;103:10192. [PubMed: 16801552]

15. a) Shao F, Elias B, Lu W, Barton JK. Inorg. Chem 2007;46:10187. [PubMed: 17973372] b) Shao F, Barton JK. J. Am. Chem. Soc 2007;129:14733. [PubMed: 17985895]

16. a) Chang IJ, Gray HB, Winkler JR. J. Am. Chem. Soc 1991;113:7056. b) Stemp EDA, Arkin MR, Barton JK. J. Am. Chem. Soc 1997;119:2921.

17. The A tract was chosen because of its resistance to inherent charge trapping. See a)Kawai K, Osakada Y, Fujitsuka M, Majima T. J. Phys. Chem. B 2007;111:2322. [PubMed: 17291027] b)Augustyn KE, Genereux JC, Barton JK. Angew. Chem 2007;119:5833. Angew. Chem. Int. Ed 2007;46:5731.

18. Liu T, Barton JK. J. Am. Chem. Soc 2005;127:10160. [PubMed: 16028914]

19. Duplexes show higher melting temperature in the Ir band $(365 \mathrm{~nm})$ than in the DNA band $(260 \mathrm{~nm})$ by $9-10^{\circ} \mathrm{C}$. This indicates that the complex prevents the two end strands from separating. This observation is characteristic of a DNA complex containing an intercalated planar ligand and has already been observed in other systems. See a)Kitamura Y, Ihara T, Okada K, Tsujimura Y, Shirasaka Y, Tazaki M, Jyo A. Chem. Commun 2005:4523. b)Ossipov D, Pradeepkumar PI, Holmer M, Chattopadhyaya J. J. Am. Chem. Soc 2001;123:3551. [PubMed: 11472126]

20. Inosine is structurally similar to guanosine but has a higher oxidation potential. Therefore, if ${ }^{\mathrm{CP}_{\mathrm{C}}}$ is oxidized, a higher extent of decomposition is expected when ${ }^{\mathrm{CP}} \mathrm{C}$ is base-paired to inosine rather than to guanosine, as less competition for hole formation is expected. No decomposition enhancement with inosine versus guanine indicates that a different process other than hole formation must be involved. See Refs. [11] and [13] for further discussion.

21. Shao F, Augustyn KE, Barton JK. J. Am. Chem. Soc 2005;127:17445. [PubMed: 16332096] 


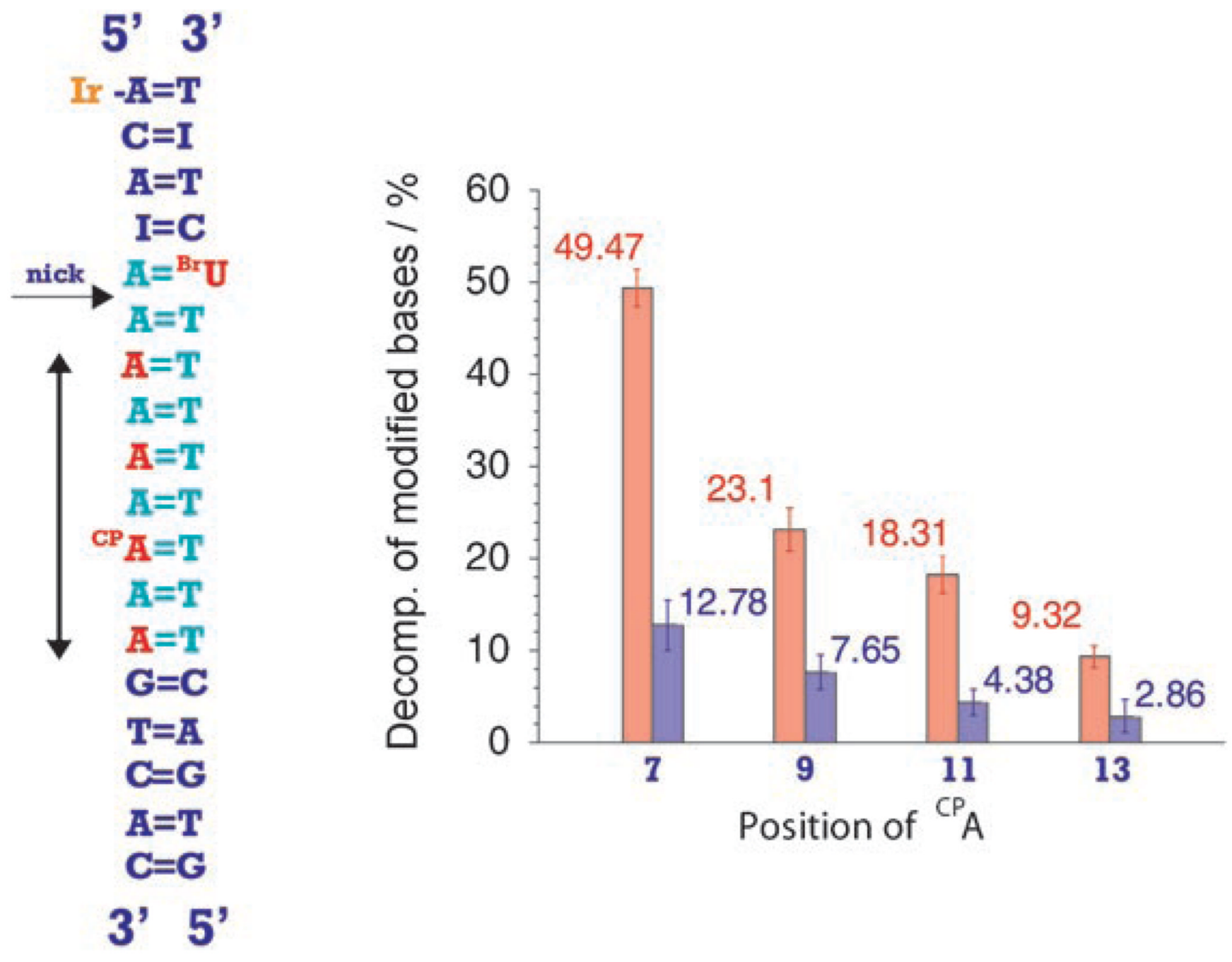

Figure 1.

Decomposition percentage for ${ }^{\mathrm{CP}} \mathrm{A}$ (red) in position 7, 9, 11, or 13 from Ir attachment and ${ }^{\mathrm{Br}} \mathrm{U}$ (blue) in position 5 from Ir after 30 min irradiation $(365 \mathrm{~nm})$. 


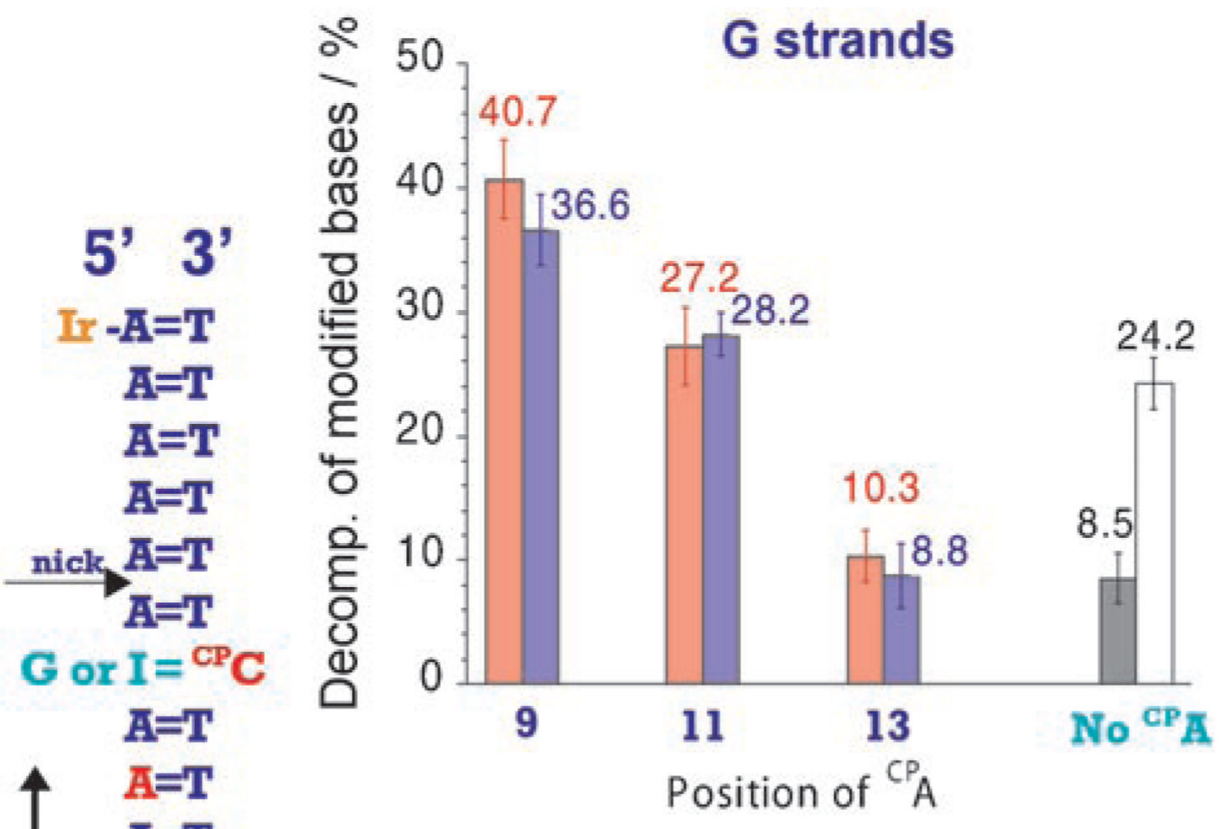

$\bar{A}=\mathbf{T}$

${ }^{\mathrm{CP}} \overline{\mathrm{A}}=\mathbf{T}$

$\bar{A}=T$

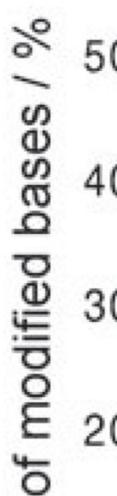

I strands

$\mathbf{G}=\mathbf{C}$

$\mathbf{T}=\overline{\mathbf{A}}$

$\mathbf{C}=\mathbf{I}$

$\bar{A}=\mathbf{T}$

$\mathbf{C}=\mathbf{G}$

3' 5'

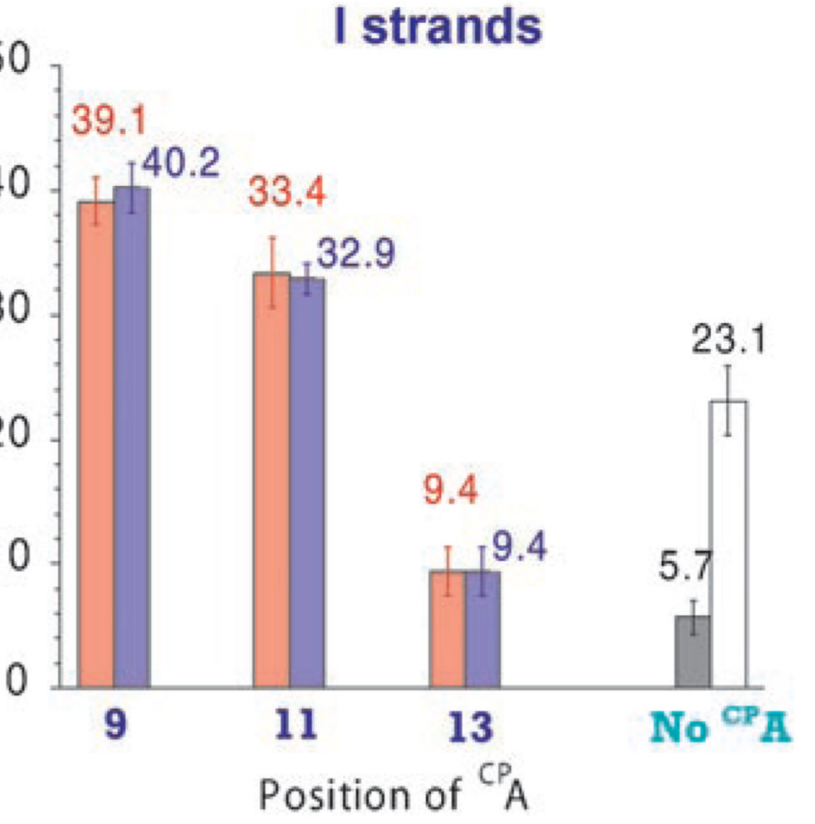

Figure 2.

Decomposition percentage for ${ }^{\mathrm{CP}} \mathrm{A}$ (red) in position 9,11 , or 13 from Ir attachment and ${ }^{\mathrm{CP}}{ }_{\mathrm{C}}$ (blue) in position 7 from Ir after $30 \mathrm{~min}$ irradiation $(365 \mathrm{~nm})$. The ${ }^{\mathrm{CP}} \mathrm{C}$ is base-paired either to a guanine (left) or to an inosine (right). In both cases, the gray and white bars show the decomposition percentage for ${ }^{\mathrm{CP}} \mathrm{C}$ without the presence of ${ }^{\mathrm{CP}} \mathrm{A}$, with (white) or without (gray) an external reductive quencher (sodium ascorbate, $200 \mathrm{~mm}$ ). 


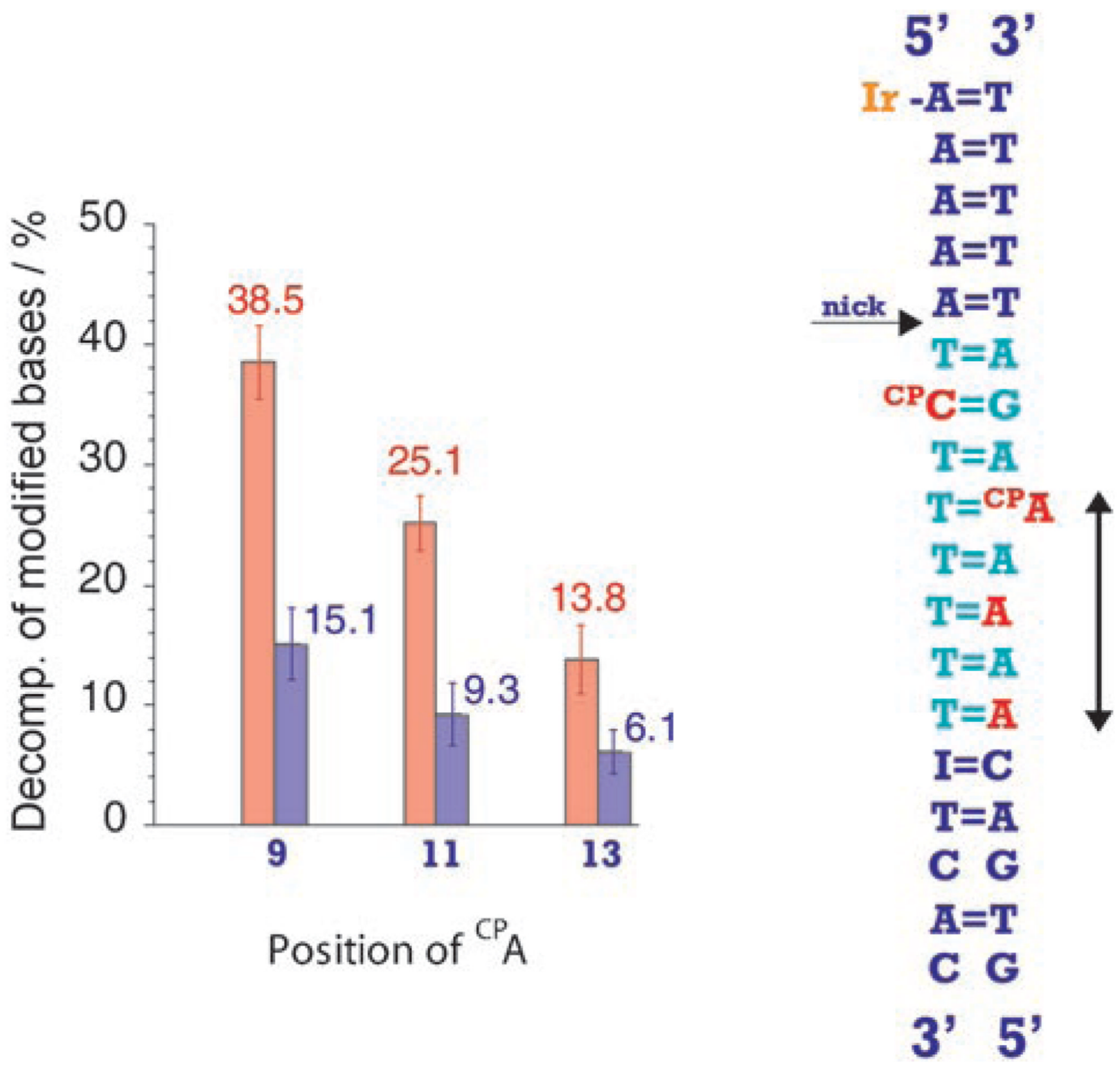

Figure 3.

Decomposition percentage for ${ }^{\mathrm{CP}} \mathrm{A}$ (red) in position 9, 11, or 13 from Ir attachment and ${ }^{\mathrm{CP}_{\mathrm{C}}}$ (blue) in position 7 from Ir after $30 \mathrm{~min}$ irradiation $(365 \mathrm{~nm})$. Both the AT tract and the ${ }^{\mathrm{CP}} \mathrm{A}$ and ${ }^{\mathrm{CP}} \mathrm{C}$ have been flipped compared to sequences presented in Figure 2. 


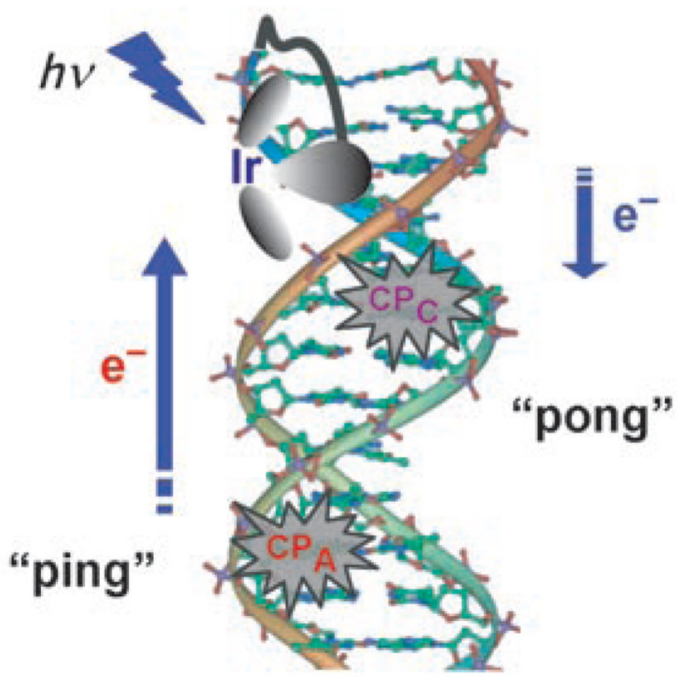<smiles>[R]n1cnc2c(NC3CC3)ncnc21</smiles><smiles>[R]n1cc(Br)c(=O)[nH]c1=O</smiles><smiles>[BiH]</smiles><smiles>[R]n1ccc(NC2CC2)nc1=O</smiles>

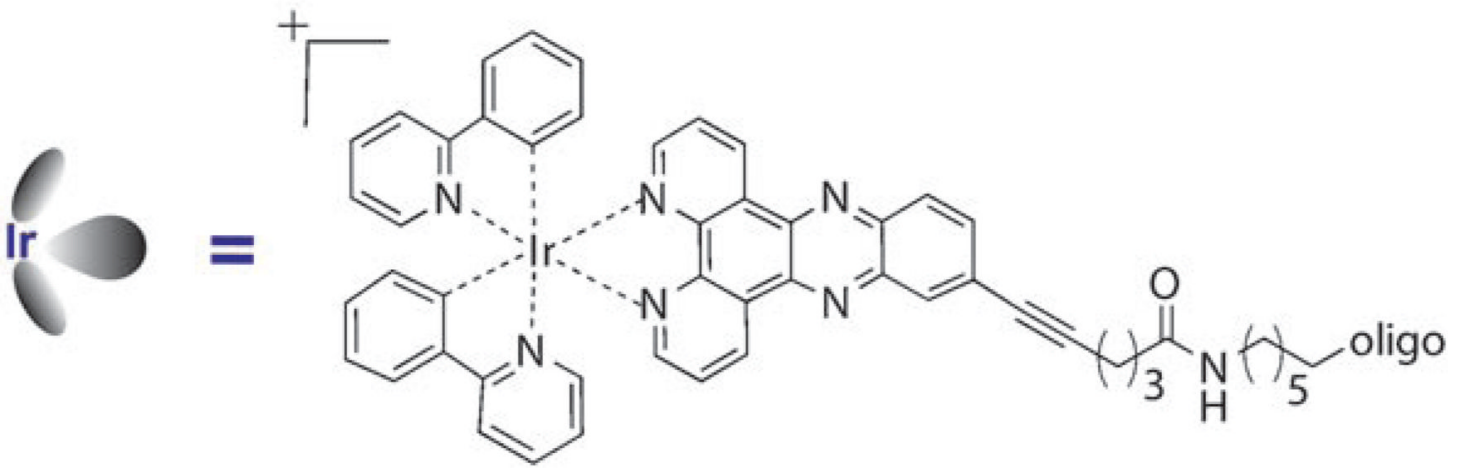

Scheme 1.

Representation of the ping-pong reaction generated through photoactivation of an Ir-DNA assembly along with modified base traps for hole $\left({ }^{\mathrm{CP}} \mathrm{A}\right)$ and electron $\left({ }^{\mathrm{Br}} \mathrm{U}\right.$ and $\left.{ }^{\mathrm{CP}} \mathrm{C}\right)$ transport. Upon excitation, the excited $\mathrm{Ir}^{\mathrm{III}}$ complex irreversibly oxidizes a ${ }^{\mathrm{CP}} \mathrm{A}$ base from a distance. The subsequent reduced metallic species is, in turn, able to reduce distal ${ }^{\mathrm{Br}} \mathrm{U}$ or ${ }^{\mathrm{CP}} \mathrm{C}$ bases. 

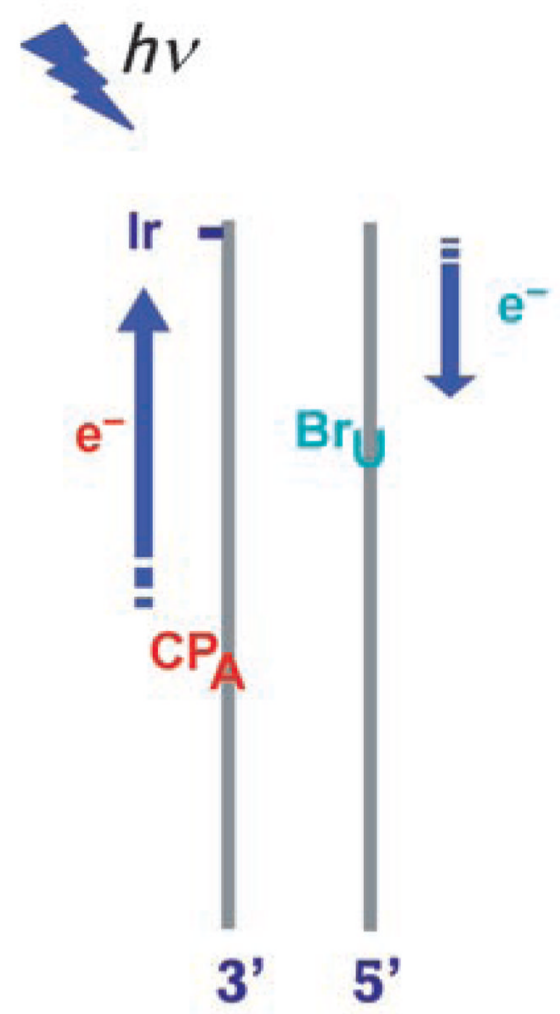

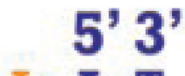

Ix $-\mathrm{A}=\mathbf{T}$

$\mathbf{C}=\mathbf{I}$

$\bar{A}=\mathbf{T}$

$\mathrm{I}=\mathrm{C}$

$\mathrm{A}={ }^{\mathrm{B}} \mathrm{U}$

$\overline{\mathrm{A}}=\mathrm{T}$

$\bar{A}=\mathbf{T}$

$\overline{\mathrm{A}}=\mathrm{T}$

${ }^{\mathrm{CP}} \overline{\mathrm{A}}=\mathbf{T}$

$\bar{A}=\mathbf{T}$

$\bar{A}=\mathbf{T}$

$\bar{A}=\mathbf{T}$

$\overline{\mathbf{A}}=\mathbf{T}$

$\mathbf{G}=\mathbf{C}$

$\mathbf{T}=\overline{\mathbf{A}}$

$\mathbf{C}=\mathbf{G}$

$\mathbf{A}=\mathbf{T}$

$\mathbf{C}=\mathbf{G}$

3' 5'
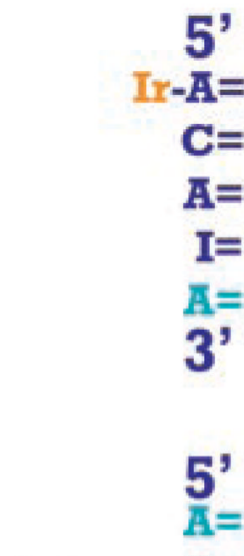

$=\quad \overline{\mathrm{A}}=$

A $=$

${ }^{\mathrm{CP}} \overline{\mathrm{A}}=$

$\overline{\mathrm{A}}=$

A $=$

$\bar{A}=$

A=

$\mathbf{G}=$

$\mathbf{T}=$

C=

A $=$

C=

3'

$=\mathbf{T}$

$=\mathrm{C}$

${ }^{\mathrm{B}} \mathrm{U}$

$=\mathrm{T}$

$=\mathbf{T}$

$=\mathbf{T}$

$=\mathbf{T}$

$=\mathrm{T}$

$=\mathbf{T}$

$=\mathbf{T}$

$=\mathrm{T}$

$=\mathrm{C}$

$=\bar{A}$

$=\mathbf{G}$

$=\mathbf{T}$

$=\mathbf{G}$

Scheme 2.

The assembly of three modified DNA single strands annealed to generate the Ir-DNA duplex for the ping-pong reaction. 